\title{
Automated test system for evaluation of corporate and management staff competencies
}

\author{
Anastasia S. Shadskaya \\ Department of Management \\ National Research Tomsk Polytechnic University \\ Tomsk, Russia \\ yrganastasia@mai.ru \\ Elena S. Yudina \\ Human Resources Division \\ National Research Tomsk Polytechnic University \\ Tomsk, Russia \\ yudinaes@tpu.ru \\ Andrey S. Latyshev \\ Vice-Rector for Human Resources \\ National Research Tomsk Polytechnic University \\ Tomsk, Russia \\ latyshevas@tpu.ru
}

\author{
Viktor V. Malyshev \\ Institute of Natural Resources \\ National Research Tomsk Polytechnic University \\ Tomsk, Russia \\ malyshevvv@tpu.ru \\ Valeriya V. Matsuta \\ Human Resources Division \\ National Research Tomsk State University \\ Tomsk, Russia \\ matsuta-vv@mail.ru
}

\begin{abstract}
The paper elaborates and extends the meaning of automated test system for the evaluation of corporate and management staff competencies. This is an experience of creating the system with such characteristics as: simple and reliable in operation, a low cost and broad functionality, installation of it directly on the server of the customer company, ensuring the confidentiality, security of personal data and the handling of the evaluation process. Moreover, it can be configured directly to those competencies that are relevant to specific companies.
\end{abstract}

Keywords-human resources, corporate and management competencies, test system, automatization

\section{INTRODUCTION}

Competency-based approach in various fields of human resource management is widespread in the modern personnel management. Large international corporations have been successfully working on the creation and development of competencies system, the possession of which is able to lead to good practical results and ensure effective management of the company. [1] Most Western companies came to conclusion about this way rather long time ago. In Russia a lot of companies apply the personnel management competencies system including such leaders of their sectors as: OJSC "NK" Rosneft", OJSC" Gazprom ", OJSC" Russian Railways ", State Corporation" Rosatom " and many others, including medium-sized companies in the private sector. This is not surprising, since the competency model is the optimal method of evaluation of personnel in the process of selection, evaluation, identification of talents and determination of training requirements. Based on the tasks, personnel management competencies policy, is able to ensure an effective decision to the three main objectives of human resource management:

- Effective recruitment and staff selection.
- Personnel development and career advancement management.

- Remuneration and motivation management.

One of the classical definitions of competences states: "Competence is the basic quality of the individual that has a causal relationship to the efficient and/or the best fulfillment based on the criteria in the job or in other situations". [2] At the same time, it is significantly, that the concept of "competence" still has no generally accepted definition. [3] In this paper, under the competence of the staff we understand, first of all, a conscious and controlled display of behavioral indicators in specific environments and situations, allowing solving work tasks more effectively, thus, dividing competences into three main parts: Corporate, Management and Technical (trade) [4]. In our opinion, "personal competence" allocated by a number of researchers' [5] are unnecessarily complicate element in the model and in real conditions of Russian enterprises are not taken into consideration or declared to be important, but not really valued. The challenge for rapid and accurate assessment of competencies including automated methods, going outside the scope of frames test knowledge compilation is extremely nontrivial, but nevertheless fairly successfully achieved primarily for technical competence in a number of industries. Today in Russia there are genuine software and solutions that enable to provide specialist testing process for the selection of specific technical competences on the basis of the competency-based approach. Result of the introduction of an automated competency assessment system in some fields is not only the formation of a project team that is able to solve the task, but also the formation of precise plans and programs for training personnel in areas where the knowledge gaps are identified, but there is no possibility to find equivalent replacement as soon as possible $[6,7]$. 
However, the situation with the assessment of corporate and, particularly, managerial competence remains rather complicated. As a rule, this type of competencies is assessed during costly (both in terms of time consumption, qualification and labor remuneration) assessment center or due to automated, including remote, battery test, which are adapted to Russia be western techniques. Particularly, the modern Russian market can distinguish such companies as Talent Q1 or CEB's SHL Talent Measurement Solutions2, which provide the widest range of services in the automated potential evaluation and abilities of employees. Nevertheless, in our opinion, there is a necessity for more efficient evaluation system of corporate and managerial competencies which must possess the following features: be simple and reliable to operate, have a low cost with broad capacity, be installed directly on the servers of the company customer, ensure the confidentiality, security of personal data and the manageability of the evaluation process, as well, focus directly on those competencies that are relevant to a particular company, taking into account the specifics of its activities.

\section{AUTOMATED TEST SYSTEM CONCEPT}

As a part of the integrated project "Services for the development and implementation of a consulting project of corporate competencies model", made in TPU for the period 2016 year for one of the largest private oil companies in Russia, among other works, the problem was solved by the development of an approach to the formation of the competence questionnaire to carry out pre-assessment of the level of corporate and managerial skills of the candidate in an automated way based on the data test.

Tested in an automated software product it consists of three phases and intends to identify a standardized behavior sample (model) of an assessed in accordance with the approved model of corporate and/or managerial skills, expressed in a numerical scale and system of categories. Application of this method allows increasing the objectivity of the decisions in the process of selection and evaluation, providing equal opportunity for all candidates. The suggested test is a personality questionnaire aimed at achieving the most objective assessment of competency by standardizing regulations, test execution time, the content and their interpretation in an automated way. During testing, the accuracy of estimation is further ensured by the distinguishing of the three stages, each of which has its own task and not an objectively observable for the candidate, which reduces the risk of a large number of socially significant responses and their impact on test results.

\section{METHODOLOGY}

Methodology of the first phase of testing assumes that an employee or applicant is asked adjusting questions and statements relating to its working activity. Tested points out what behavior at work for him is supposed to be the most or the least typically and how often he demonstrates it. Each of the sets of questions is designed to evaluate one of the indicators of each competency.
TABLE I METHODOLOGY. SAMPLE QUESTIONS OF THE FIRST PHASE OF TESTING

Current loyalty 59:18 left for test to be completed

\begin{tabular}{|c|c|c|c|c|c|c|}
\hline Indicators & 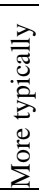 & 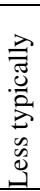 & $\begin{array}{l}8 \\
8 \\
8 \\
\infty \\
2 \\
\frac{1}{3} \\
\frac{1}{4}\end{array}$ & 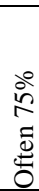 & 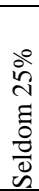 & 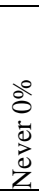 \\
\hline $\begin{array}{l}\text { If the decision of working task } \\
\text { requires infringement of labor } \\
\text { discipline, you will search for } \\
\text { another solution or refuse. }\end{array}$ & V & & $\mathbf{V}$ & & & \\
\hline $\begin{array}{l}\text { If it is necessary to violate } \\
\text { labor disciple when solving } \\
\text { working task, you can do that } \\
\text { as the results are more } \\
\text { important for Company. }\end{array}$ & & & & & & \\
\hline $\begin{array}{l}\text { You consider following the } \\
\text { labor discipline is obligatory } \\
\text { for you. }\end{array}$ & & $\mathbf{V}$ & & V & & \\
\hline $\begin{array}{l}\text { In case the employee is } \\
\text { effective, an employer can } \\
\text { ignore the fact of violating } \\
\text { labor discipline. }\end{array}$ & & & & & & \\
\hline
\end{tabular}

According to the second phase the candidate is given one test question for each indicator of each competency, and thus formed a preliminary assessment of each competency. The third phase IS implicitly reflected in the various blocks of the test where the employee is given challenge questions on "the scale of lies". In the case of testing the system detects a tendency employee to socially approved answers adjusted overall assessment competency, which is supposed to be the final.

TABLE II METHODOLOGY. SAMPLE QUESTIONS OF THE SECOND PHASE OF TESTING

\begin{tabular}{|c|c|c|c|c|c|}
\hline Clarifications & 1 & 0,5 & 0,25 & 0,5 & 1 \\
\hline $\begin{array}{l}\text { How often do you violate } \\
\text { labor discipline? }\end{array}$ & 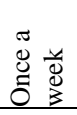 & 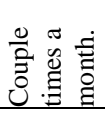 & 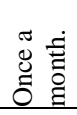 & 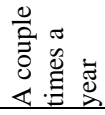 & $\begin{array}{l}\bar{D} \\
\dot{0} \\
\end{array}$ \\
\hline $\begin{array}{l}\text { How often do you raise } \\
\text { your voice when you } \\
\text { colleague let you down not } \\
\text { performing his own duties. }\end{array}$ & 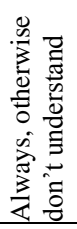 & 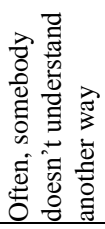 & 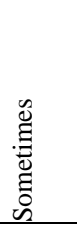 & $\begin{array}{l}\frac{\Xi}{0} \\
\frac{0}{0} \\
\frac{0}{2} \\
\frac{0}{2}\end{array}$ & 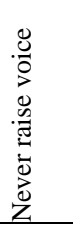 \\
\hline $\begin{array}{l}\text { When was the last time } \\
\text { you had a contradiction } \\
\text { situation because of } \\
\text { misunderstanding your } \\
\text { duties. }\end{array}$ & 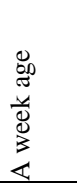 & 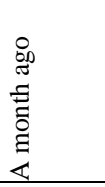 & 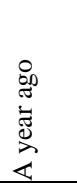 & 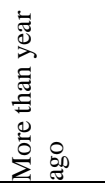 & 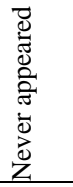 \\
\hline $\begin{array}{l}\text { How often do you take a } \\
\text { decision in } \\
\text { correspondence with } \\
\text { Company standards? }\end{array}$ & $\sum_{\substack{i \\
\Sigma}}^{\infty}$ & 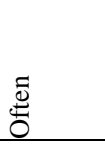 & 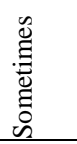 & $\begin{array}{l}\text { ह } \\
\frac{0}{0} \\
\tilde{D}\end{array}$ & $\begin{array}{l}\bar{D} \\
\grave{z} \\
z\end{array}$ \\
\hline $\begin{array}{l}\text { When was the last time } \\
\text { you discussed the } \\
\text { development prospects of } \\
\text { the Company? }\end{array}$ & 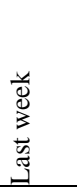 & 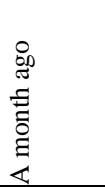 & 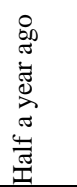 & 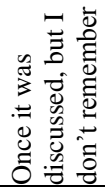 & 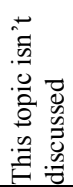 \\
\hline
\end{tabular}




\begin{tabular}{|c|c|c|c|c|c|}
\hline $\begin{array}{l}\text { How often do your } \\
\text { colleagues follow you at } \\
\text { working process? }\end{array}$ & 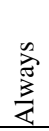 & 巳ี & 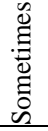 & $\begin{array}{l}E \\
\frac{0}{0} \\
\tilde{D} \\
\end{array}$ & $\begin{array}{l}\bar{D} \\
\overline{0} \\
z\end{array}$ \\
\hline $\begin{array}{l}\text { How often do your } \\
\text { personal actions give } \\
\text { positive result to your } \\
\text { colleagues? }\end{array}$ & 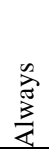 & 总 & 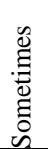 & $\begin{array}{l}\Xi \\
\frac{0}{0} \\
\frac{0}{0} \\
\infty\end{array}$ & $\begin{array}{l}\bar{D} \\
\bar{d} \\
\bar{z}\end{array}$ \\
\hline
\end{tabular}

All work on the input of employee data for testing and processing of results takes place in a fully automated way. According to the test results, the employees of the Department of Personnel Management have access to report with two versions of the graphical display of competency evaluation and extended test data that can be used as a basis for interviews on competences and/or an in-depth assessment center. Observation of the data about the employee and the evaluation of the results is available in a separate section of the automated system, which displays information about the employee, the list of competencies and the desired level of development according to the position and the result passed evaluation.

TABLE III $\quad$ EXAMPLE OF DISPLAY ON THE PASSED DATA TEST

\begin{tabular}{|l|l|l|l|l|l|}
\hline $\begin{array}{l}\text { Results of passed test. } \\
\text { Data of last evaluation: 03.11.2015 15:16:25 }\end{array}$ & & & & & \\
\hline \multicolumn{1}{|c|}{ Corporate competencies } & 1 & 2 & 3 & 4 & 5 \\
\hline $\begin{array}{l}\text { Professionalism } \\
\text { Knows his/her professional skills, } \\
\text { develops them and works within his } \\
\text { competence proactively. }\end{array}$ & V & V & V & \\
\hline $\begin{array}{l}\text { Loyalty } \\
\text { Consider being in line with standards, } \\
\text { values and interests of Company to be a } \\
\text { determining factor in working behavior. }\end{array}$ & & & & & \\
\hline $\begin{array}{l}\text { Initiative } \\
\text { Behaves as an active and self-sufficient } \\
\text { employee in actions aimed at achieving } \\
\text { working and administrative goals. }\end{array}$ & V & V & V & V & \\
\hline $\begin{array}{l}\text { Effectiveness } \\
\text { Implements his/her set plans } \\
\text { effectively. }\end{array}$ & V & & & & \\
\hline $\begin{array}{l}\text { Team spirit } \\
\text { Sees himself/herself as a part of one } \\
\text { team achieving one result. }\end{array}$ & V & V & & & \\
\hline $\begin{array}{l}\text { Responsibility } \\
\text { Takes the responsibility for his/her own } \\
\text { and for his/her employees work when } \\
\text { solving the problems. }\end{array}$ & V & V & V & & \\
\hline
\end{tabular}

In the example above, the desired level of competence has blue color Bucket. The actual level has green color Bucket with the marker way. In case the actual rate exceeds the desired, yellow marker will be displayed. Each passed competency is available to be viewed with the detailed report and the results of testing up to view the test results for each individual indicator of competence that allows systematic to analyze of the strengths and weaknesses of employee or candidate for employment.

\section{TABLE IV A DETAILED REPORT ON CORPORATE COMPETENCY "PROFESSIONALISM"}

Professionalism

Know his professional skills, develop them and work within his

\begin{tabular}{|c|c|c|c|c|c|}
\hline \multicolumn{6}{|l|}{ competence proactively. } \\
\hline $\begin{array}{l}\text { Grade } 4(4) \\
\text { Experience level } 1 . \\
\text { Demonstrate competency } \\
\text { in most working cases. } 2 . \\
\text { Initiative demonstrate } \\
\text { correct behavior }\end{array}$ & 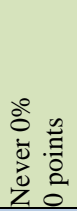 & 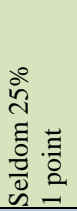 & 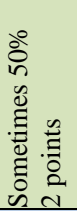 & 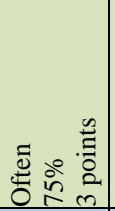 & 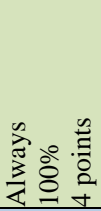 \\
\hline $\begin{array}{l}\text { Know and perform key } \\
\text { standards and regulations } \\
\text { of Company and apply } \\
\text { them in your working } \\
\text { process. }\end{array}$ & $\mathbf{V}$ & $\mathbf{V}$ & $\mathbf{V}$ & $=1$ & $4=\sqrt{2}$ \\
\hline $\begin{array}{l}\text { Find and develop } \\
\text { possibilities to increase } \\
\text { work effectiveness } \\
\text { according to aims and } \\
\text { perspectives of team } \\
\text { development, department } \\
\text { and Company. }\end{array}$ & $\mathbf{V}$ & $\mathbf{V}$ & $\mathbf{V}$ & & \\
\hline $\begin{array}{l}\text { Assess the strength and } \\
\text { weaknesses objectively } \\
\text { taking the decisions. }\end{array}$ & $\mathbf{V}$ & & & & \\
\hline $\begin{array}{l}\text { Demonstrate high working } \\
\text { capacity in stress } \\
\text { conditions, under pressure, } \\
\text { having lack of time and } \\
\text { information. }\end{array}$ & & & & & \\
\hline $\begin{array}{l}\text { Is able to introspect. Make } \\
\text { conclusion out of his } \\
\text { mistakes, apply successful } \\
\text { decisions in practice and } \\
\text { share it beyond his } \\
\text { experience. }\end{array}$ & $\mathbf{V}$ & $\mathbf{V}$ & & & \\
\hline $\begin{array}{l}\text { Use unconventional } \\
\text { approach in solving } \\
\text { problems. Combine } \\
\text { different decisions and } \\
\text { components, solve the } \\
\text { problems in a holistic } \\
\text { manner }\end{array}$ & $\mathbf{V}$ & & & & \\
\hline $\begin{array}{l}\text { Follow innovations in his } \\
\text { professional sphere and } \\
\text { implement them into his } \\
\text { work. }\end{array}$ & $\mathbf{V}$ & $\mathbf{V}$ & $\mathbf{V}$ & $\mathbf{V}$ & $\mathbf{V}$ \\
\hline
\end{tabular}

The system has a number of additional features, such as added section, which containd lists of materials for the development of competencies in the form of documents, presentations, videos, links to Internet resources, books, regulations, etc., for the specialists in the HR department to fill it with any additional materials. According to test results, if the target result of the employee does not correspond to the planned, the system automatically recommends the materials for self-development for some underdeveloped competency.

\section{CONCLUSION}

As a result of the implementation of IT solutions in the real work of the oil company, including two stages of pilot testing, the development of materials for the customer's specialists, including the regulation of using the system, a user manual, seminars for training and, finally, the working operation of the system during the 4th quarter 2015 - 1st quarter of 2016, we believe it is possible to highlight the key benefits and features of the IT solutions developed in TPU: 
1. Unique corporate and managerial skills testing system developed exclusively for a particular Company.

2. Structural and cataloged storage of all competencies of the Company.

3. Storage of assessment tools for competency.

4. Catalogue of profiles of positions in the set form of requirements for the competence.

5. IT-solution in the form of a web application can be used from any computer of the Company without any additional installations and settings.

6. Created tool allows you to assess any number of employees at any time, including remotely.

7. Instant analysis of employee evaluation.

8. Catalog of materials for independent development of competencies

9. The mechanism allows to attach any materials for development and to make recommendations, based on results of the evaluation, automatically.

10. The centralized storage of the results of evaluations.

11. The system of authorized access.

12. Limited employee access to assessment materials. Human Resources provide access to the assessment procedure using one-time password.
13. The diverse representation of the results in the form of tables and / or graphs, allowing a visual assessment of the level of staff competence.

14. The validity of the results, confirmed by comparing the results of testing with data assessment center for employees.

These results, in our view, allow talking about a unique view of system and the possibility of its further implementation in companies of various sectors of the economy, size and forms of ownership.

\section{REFERENCES}

[1] B. I Kuzmin, Competency diagnosis in the practice of the Russian corporate management, Herald of the VolSU, №10, 2006

[2] L. M Spencer ml., S. Spencer, "Competence at work", Moscow, HIPPO, 2005, p. 384

[3] N. A Shmatko, Competence of engineering staff: experience of comparative research in Russia and EU countries, Foresight №4, 2012

[4] N. Volodin, Competency model - is not difficult [Electronic resource] // URL: http://www.kadrovik.ru/modules.php?op=modload\&name=News\&fil e=article\&sid=9037 (last accessed date: 28.03 .2016 )

[5] 5. Y. Duhnich, Personal competences [Electronic resource] // URL: http://www.smart-edu.com/lichnostnye-kompetentsii.html (last accessed date: 28.03.2016)

[6] A. Y. Dmitriev, V. V. Malyshev, D. V. Khudyakov, Design of oil and gas industry with the competence approach, Gas industry, 2014

[7] A. Y. Dmitriev, V. V. Malyshev, D. V. Khudyakov, L. V Vorobyev, Aspects of the evaluation of technical competence of specialists of oil and gas companies, Herald of the Russian Academy of Natural Sciences, West Siberian branch, Vol. 14, 2012, pp 101-107 